\title{
A CASE STUDY OF GROUNDWATER CONTAMINATION DUE TO OPEN DUMPING OF MUNICIPAL SOLID WASTE IN FAISALABAD, PAKISTAN
}

\author{
Muhammad Usman ${ }^{1 *}$, Hafsa Yasin ${ }^{1}$, Abdul Nasir ${ }^{1}$ and Waqas Mehmood ${ }^{2}$ \\ ${ }^{1}$ Department of Structures and Environmental Engineering, University of Agriculture Faisalabad, Pakistan. \\ ${ }^{2}$ Institute of Environmental Engineering Research (IEER), University of Engineering \& Technology, Lahore, Pakistan. \\ *Corresponding author's e-mail: musman03@hotmail.com
}

This is an open access article distributed under the Creative Commons Attribution License, which permits unrestricted use, distribution, and reproduction in any medium, provided the original work is properly cited

\section{ARTICLE DETAILS}

Article history:

Received 25 August 2017

Accepted 20 October 2017

Available online 7 November 2017

Keywords:

Groundwater, leachate, open dumping, pollutant

\section{ABSTRACT}

Open dumping site causes a serious environmental problem that included water, air, surface water and ground water. Ground water is very precious source of water, but it is deteriorated by leachate formation which contains many dangerous complex compounds. Nearby areas are more affected in water quality than the far-off areas. The present study explored the municipal open dumping site of Faisalabad impacts on ground water quality. Six points were selected for water sampling at different specific distances from the sites in the study area. Then the samples were examined for seven parameters that included TDS, pH, Hardness, Turbidity, Fecal Coliform and Total Coliform to investigate the affected ground water quality. Results have showed that dangerous pollutants are important component of ground water that are in more concentration then standards and is unfit for consumption. It may result to different water born diseases respiratory problems and lungs cancer etc. Proper monitoring and supervision for leachate management and waste disposal are suggested.

\section{INTRODUCTION}

Water is the most important substance which constitutes $71 \%$ of earth's surface [1]. Further, $2.5 \%$ of that is only fresh water, appropriate for utilization and even that some of it is interlocked in glaciers form [2]. The survival of life depends largely on water. Without adequate water life seems to be impossible on the earth [3]. Deficiency of water can kill the organism more rapidly than the food [4]. Several studies have evaluated that a human can live for almost 20 days without taking food but remain restless for life in the absence of water just after one day [5]. No doubt water is the most drinkable liquid, at the same time it is the most dominant source of imparting diseases in humans in the developing countries [6]. Globally water resources are under pressure, but this situation is more critical in Asian countries due to lack of management and expertise [7].

Waste is the by product. With the passage of time the waste quantity is going to be increased due to changing life patterns and increasing populations [8]. The impacts of waste on ecosystem largely depends on composition and disposing practices [9]. Domestic mainly includes household waste like kitchen waste, plastic waste, yard clippings, broken electronics, paper waste and furniture etc. Sometimes it also contains hazardous compounds [10]. Landfills and open dumping are common practices in the developing countries while latter one is more common in Pakistan because they inexpensive and easy methods of disposal but at the same time have tremendous negative affects [11]. Open dumping deteriorates the natural environmental factors in a number of ways. Water, land, air and health are the most hitting areas by open dumping [10].

Open dumping of waste has direct impact on the ground water quality. No doubt, Pakistan has fresh resources in a form of glaciers, lakes and rivers but due to changing climatic conditions, there is sacristy of rainfall and snowfall. Due to this condition Pakistan is suffering from water shortage. So, there is need to use ground water [3]. Mostly the dumping site in Pakistan are unplanned and have no proper mechanism to protect the environment from the adverse effects of dumping site. Many big cities are facing this issue related to solid waste management. When the waste is thrown openly on the surface without any treatment it imparts several complications. Bad odors of decomposed matter and littering are common phenomena. Nearby soil quality becomes damage due to pollutants. Dangerous gases methane and carbon dioxide which are major greenhouse gases emit due to burning phenomena. With all these negative impacts, the dangerous fluid along with pollutants percolate to ground water that deteriorates the water quality adversely. In order to highlight this problem, the following study was conducted. The aim of this study is the ground water analysis in dumping site of MSW of Faisalabad to determine the condition of groundwater of nearby areas so that remedial actions will be taken according to the situation of contamination.

\section{DESCRIPTION OF THE STUDY AREA}

Faisalabad which is heavily populated third largest city of Pakistan. Due to enormous increase in population, the demand for good quality water is going to be increased. Faisalabad being the Manchester of Pakistan, with large number of industrial units and wide spreading municipal colonies are producing more and more waste with the passage of time. Faisalabad has large dependence on ground water. The waste from the four towns of Faisalabad is carried to the Muhammada Wala dumping site. It is situated on Jaranwala Road and geographically it is situated at 310 23'8'nothern latitude and $73014^{\prime}$ '26" eastern longitude at $182.93 \mathrm{~m}$ above sea level.

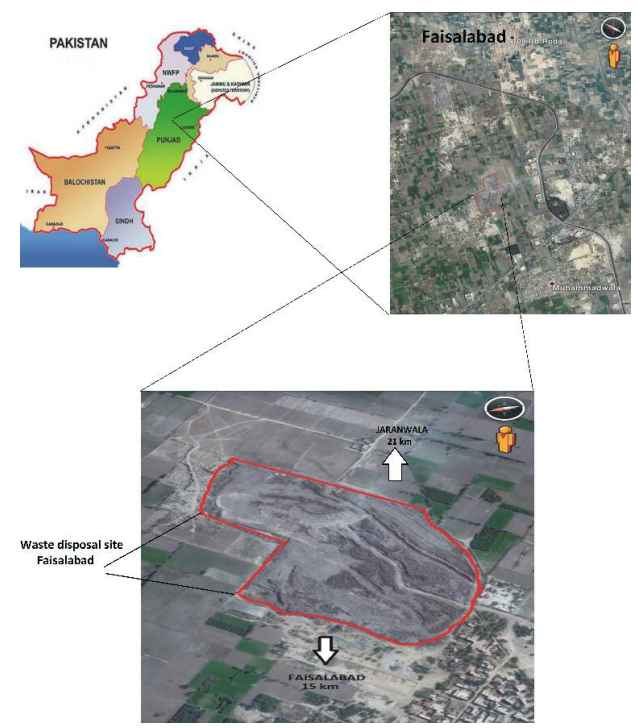

Figure 1: Muhammada wala open dumping site

Approximately 75-acre area is used for dumping. Almost 900 tons/day and above waste is carried to the site which is disposed of openly without any treatment and precautions. This dumping site is in use for more than 25 years. The waste contains organic and inorganic waste along with moisture content. Some hazardous elements are also present in waste in small quantity like heavy metals etc. When water becomes contacts with suspended and dissolved particles present in waste, becomes contaminated and percolate down by gravity called leachate. The situation becomes worsen when it rains heavily because During rainfall season as there is no protecting cover in open dumping site that shield the water to enter in the solid waste. Leachate contains a number of dangerous pollutants in complex mixtures and damages the water quality by dissolving in it. 


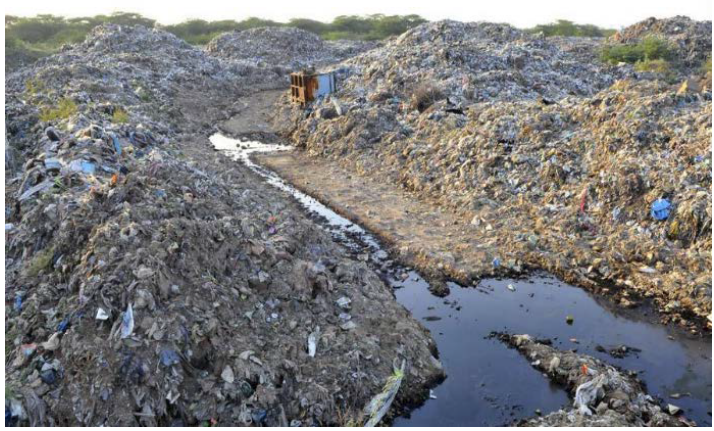

Figure 2: View of open dumping site after rain at Muhammad Wala dumping site

\section{METHODOLOGY}

In order to study the impacts of waste and leachate on ground water quality several surveys were conducted to investigate the different sampling sites. Six sampling locations were selected in the nearby vicinity of open site of Muhammada wala and their distances from the site were determined. Six samples were collected from nearby areas of dumping site. It includes nearby small unit houses and animal shed. Sterilized sampling bottles of $500 \mathrm{ml}$ were used to collect sample from six different sites. Three samples were collected from each site. One for the physical parameters, one for heavy metal and one for the biological parameters. For microbial sampling, sampling sources were cleaned with ethyl spirit and flame to prevent any impurity from external environment. The microbial samples were stored at $40 \mathrm{C}$ and immediately sent to laboratory. The depth of the water sources was between 25 to 45 meters. The distance of water sample location from the dumping site varied from 50 to 500 meters. The detail of water sample sites is presented in Table 1. Sources of water sample included hydrants and pumps.

\section{RESULTS AND DISCUSSION}

Table 1: Groundwater analysis of selected parameters

\begin{tabular}{|l|l|l|l|l|l|l|l|l|}
\hline Sample & $\begin{array}{l}\text { Distanc } \\
\mathbf{e}(\mathbf{m})\end{array}$ & $\mathbf{p H}$ & $\begin{array}{l}\text { Turbid } \\
\text { ity } \\
\mathbf{( N T U )}\end{array}$ & $\begin{array}{l}\text { TDS(m } \\
\mathbf{g} / \mathbf{l})\end{array}$ & $\begin{array}{l}\text { As(mg } \\
\mathbf{l})\end{array}$ & $\begin{array}{l}\text { Total } \\
\text { hardnes } \\
\mathbf{s}(\mathbf{m g} / \mathbf{l})\end{array}$ & $\begin{array}{l}\text { Fecal } \\
\text { Coliform } \\
\mathbf{( M P N / 1 0 0} \\
\mathbf{m l})\end{array}$ & $\begin{array}{l}\text { Total } \\
\text { Coliform } \\
\mathbf{( M P N / 1 0} \\
\mathbf{0 m l}\end{array}$ \\
\hline S1 & 50 & 8.0 & 5.0 & 2000 & 89 & 655 & 49 & 50 \\
\hline S2 & 100 & 8.2 & 4.5 & 1967 & 70 & 513 & 150 & 177 \\
\hline S3 & 150 & 7.5 & 5.0 & 1999 & 74 & 660 & 200 & 233 \\
\hline S4 & 200 & 7.7 & 2.2 & 1668 & 105 & 254 & 78 & 89 \\
\hline S5 & 250 & 8.0 & 3.8 & 1505 & 52 & 222 & 30 & 43 \\
\hline S6 & 500 & 8.2 & 3.0 & 1403 & 94 & 187 & 20 & 33 \\
\hline
\end{tabular}

The different parameters of water quality show variations from one place to another place. It shows pollutants are components of ground water and use of it is not free of risk. Indications of pollution is high near the dumping site as camper to the far-off distances. The $\mathrm{pH}$ value is a good indicator of whether the water is alkaline or acidic in nature. Values of TDS show high variation from standards which makes it unfit for consumption and water samples from closed vicinity show high TDS. High TDS has the ability to change water hardness, taste and corrosive property of water. Water is also showing the high symptoms of Arsenic which confirms the presence of hazardous waste. It is even dangerous in little quantity and causes various respiratory illness and lung cancer etc. Water samples are exhibiting total coliforms and fecal coliforms in significantly high range that confirms the presence of organic matter in ground water. Many water born diseases including diarrhea, cholera, typhoid, paratyphoid, hepatitis A, dermatitis, enteric fever, and many more are permanent health risks to the nearby residents especially children and elderly people. The high levels of bacterial contamination cause an elevated risk of waterborne gastroenteritis.

\section{CONCLUSION}

The open dumping site are accounted a serious ultimatum to the environment in all perspectives specially ground water which is a precious source of natural water. From the result is cleared that pollutants are also an important ingredient of water due to leachate flow. Groundwater quality is terrible near dumping site as compared to far off site. Microbial pollutants and heavy metals present in water is very serious threat to public health. It is cleared from the study that open dumping site near Muhammada Wala is affecting the ground water quality due to the mismanagement of waste and leachate at the site.

\section{RECOMMENDATION}

- $\quad$ There should be proper landfill site with proper controlling of leachate flow.

- Proper segregation at the source is highly recommended. Government and authorities must play their role jointly in - spreading awareness about organizing waste and develop operational staff training programs and workshops.

- $\quad$ There should be a proper monitoring and supervision of the sites for controlling of different types of pollutions and for the betterment of the public health of the nearby area.

- There should strict implementation of environmental laws related to waste disposal and handling within the municipality.

- There should be a cover head or net on the waste to prevent the flow of leachate during rainfall.

- $\quad$ Dumping site should have well developed strong foundation or base to prevent the entry of leachate to ground water. Wet waste and dry waste should be disposed of separately.

\section{REFERENCES}

[1] NERC. 2007. The Oceans: Scientific certainties and uncertainties. National Environment Research Council, Swindon, England.

[2] Juneja, T., and Chaudhary, A. 2013. Assessment of water quality and its effects on the health of residents of Jhunjhunu district, Rajasthan: A cross sectional study. Journal of Public Health and Epidemiology, 5 (4), 186-191.

[3] Baloch, M., and Ahmad, S.A. 2012. Water pollution: Major issue in urban areas. International journal of water resources and environmental engineering, 4 (3), 55-65.

\section{[4] Chattarjee, C.C. 1983. Human physiology. Calcatta, India. pp. 33.}

[5] Srivastava, Y.N. 1995. Environmental pollution. Ashish Pub. House, New Delhi, p. 35.

[6] Tebbutt, T.H. 1983. Principles of water quality control. 3rd Edn. Pergaman Press Oxford. p. 42

[7] Muhammad, A.M., and Zhonghua, T. 2014. Municipal Solid Waste and its Relationship with Groundwater Contamination in Lahore, Pakistan. Research journal of applied sciences, engineering and technology, 7 (8), 1551-1560.

[8] Rajkumar,N. Subramani,T. and Elango,L. 2010. Groundwater Contamination Due to Municipal Solid Waste Disposal: A GIS Based Study in Erode City. International journal of environmental sciences, 1, 39-55.

[9] Namen, A.A., Brasil Fda, C., Abrunhosa, J.J., Abrunhosa, G.G., Tarre, R.M., and Marques, F.J. 2014. RFID technology for hazardous waste management and tracking. Waste Management, 32, 59-66

[10] Yasin, H., and Usman, M. 2017. Site investigation of open dumping site of municipal solid waste in Faisalabad. International journal of earth sciences Pakistan, 1 (1), 23-25.

[11] Ghaffar, A., and Butt, I. 2012. Ground Water Quality Assessment Near Mehmood Boti Landfill, Lahore, Pakistan. Asian journal of social sciences and humanities, 1 (2), 13-24.

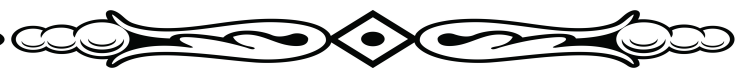

